\title{
Habitat and Phytochemical Analysis of Gemor (Nothaphoebe sp.) on Peat-swamp Forest Areas, Central Kalimantan
}

\author{
Yudi Firmanul Arifin ${ }^{1,2, *}$, Siti Hamidah ${ }^{1,2}$, Trisnu Satriadi ${ }^{1,2}$, Gusti Muhammad Hatta ${ }^{1,2}$ \\ ${ }^{1}$ Faculty of Forestry, Lambung Mangkurat University, Indonesia \\ ${ }^{2}$ Research Consortium for Sustainable Tropical Forest Management, Indonesia
}

Copyright $\bigcirc 2017$ by authors, all rights reserved. Authors agree that this article remains permanently open access under the terms of the Creative Commons Attribution License 4.0 International License

\begin{abstract}
Gemor is one of the forest products of high economic value. The bark can be used for the manufacture of mosquito coils; so many people collect them for sale. The selling price of wet-bark reaches 231-385 USD per ton. High prices of Gemor lead to increased exploitation. Conservation efforts are not done yet, so this species will be endangered. This study was conducted to determine the characteristics of Gemor habitat and phytochemical confounds of leave, twig, and bark. From this research which part can produce insecticide besides stem bark can be known.It can be used for an alternative for utilization of Gemor besides bark. It was revealed that the Gemor tended to live well on habitats which have on peatlands, sometimes flooded, $\mathrm{pH}$ of $3.52-3.58$, and pyrite of $0.17-0.21 \%$. It needed $\mathrm{N}$ of $1.21-1.43 \%, \mathrm{P}$ of $9.00-9.10 \mathrm{mg} / 100 \mathrm{~g}, \mathrm{C}$ of $3.78-9.29 \%$. This species was living generally in secondary forests with a light intensity of 3-5\% and humidity of $88-99 \%$. Phytochemical analysis indicated the other anatomy of Gemor besides the bark, namely leaves and twigs also contain secondary metabolites, such as; alkaloids, steroids, flavonoids, and phenolic. Flavonoids and phenolic compounds were potentially as natural insecticides. Flavonoids and phenolic in leaves were higher than the bark, so it can be said that the leave of Gemor was potentially as natural insecticides.
\end{abstract}

Keywords Gemor, Habitat, Phytochemical Analysis, Conservation

\section{Introduction}

One of non-timber forest products produced from peat swamp forests is bark of Gemor. Gemor has been identified as the family of Lauraceae and the genus of Alseodaphne and Nothaphoebe. Two species of wood Gemor used by the society, namely; Nothaphoebe cariacea Kostern and
Nothaphoebe cf. umbelliflora [3] had been found. The distribution of Gemor occurs in Sumatra, Kalimantan and Papua, but the best quality of bark is found in Kalimantan, especially in Central Kalimantan [7]. The population in Central Kalimantan covers Sampit, Sebangau National Park, Katingan, and Palangkaraya [7].

Gemor (Nothaphoebe spp.) became one of the tree species with high economic value because it has a variety of utilizations. It exported to several countries, including Taiwan, Singapore, Japan. The bark was known as the basic material for making repellent. The barks can be used as the main raw material in the manufacture of anti-mosquito drugs, incense, and adhesive $[3,7,16]$.

The demand of bark was always increasing however the raw materials were more difficult to be obtained in natural forest. In 2012 highest price increases of $87.5 \%$, compared to price in 2011. Highest export price in 2011 reached 5,368 USD [20]. Normally bark of gemorfrom Central Kalimantan was sold to collectors in Banjarmasin [10]. They sold generally just Nothaphoebe cariacea Kosterrn, because it was still widely available in natural forest.

Based on the description above, we tried to analyze habitat of Gemor for the purpose of cultivation. We want to know the content of secondary metabolites of each species of Gemor in Central Kalimantan. The research also determined trend of the other parts of anatomical Gemor (leaves and twigs) beside the bark that can also be used as a natural insecticide.

\section{Research Methodology}

\subsection{Field Survey}

Field surveys were carried out to determine sample point of Gemor habitat. The sample plots were designed purposively at the areas where the Gemor occured. Generally 
location of Gemor was obtained from some respondents, such as;manager of KHDTK Tumbang Nusa, the collectors from Sebangau National Park, people around KHDTK Tumbang Nusa [22]. If the areas of gemor habitat were found, wecollected soil samples, to measure topography and micro-climates.

\subsection{Collection and Identification of Plant Materials}

The fresh leaves, twigs and bark was collected from Tumbang Nusa and Sebangau National Park, Central Kalimantan, Indonesia. The location and species of Gemor was known based on the information from gatherers and manager of KHDTK Tumbang Nusa. Samples were identified to determine each species.

\subsection{Preparation of Extracts}

Parts of anatomical plant (twigs, leaves and bark) were used as materials.It wascleaned with water (preferably with water flow), and then dried. The dried of materialswere put in a plastic bag so that the sample is maintained freshness. The materials were cut to become small size and then it was made powder using a commercial blender [6].

The preparation of materials (leaves, twigs and bark) into powder can be seen in Figure 1 below:

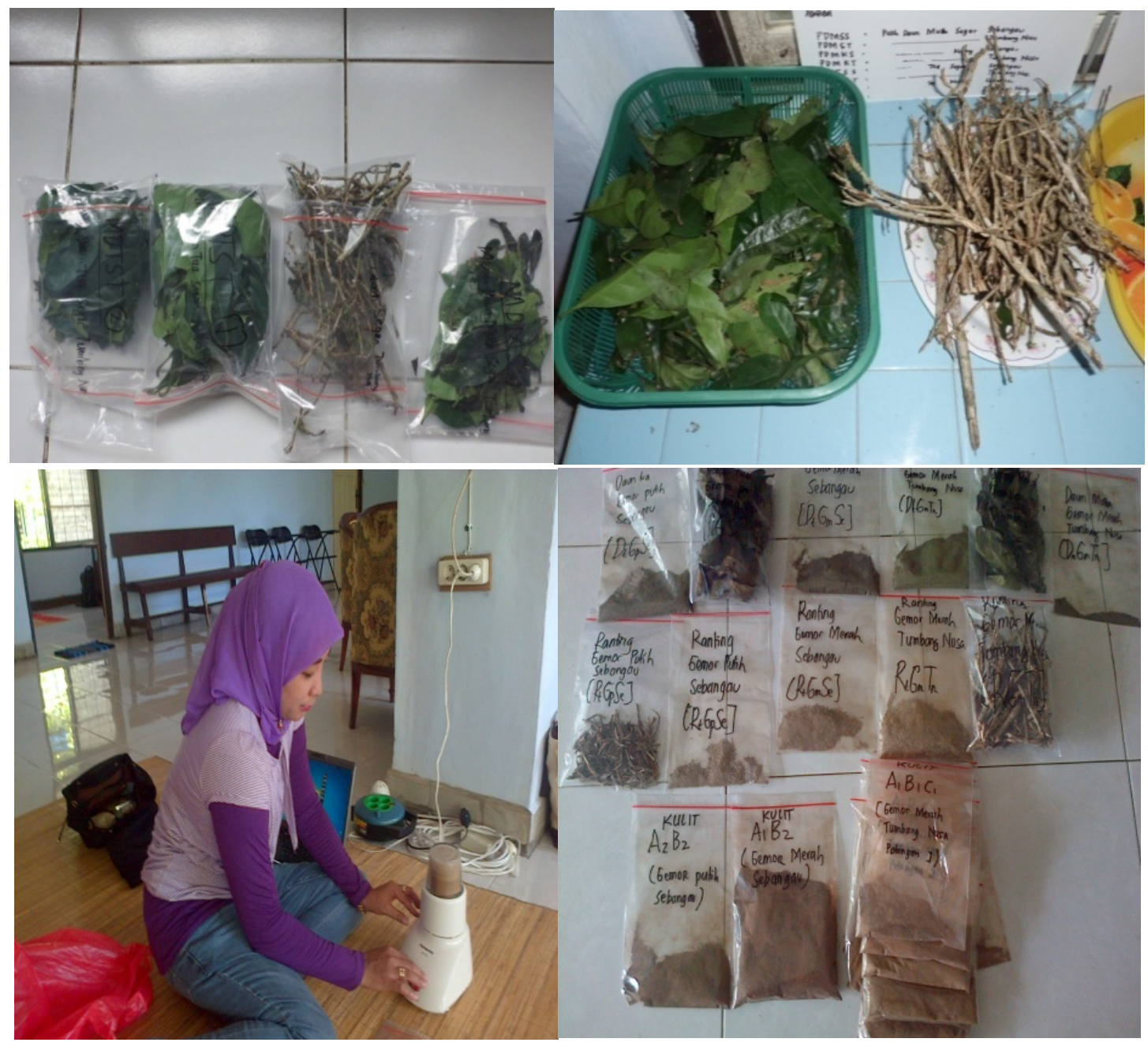

Figure 1. Preparation of research materials 


\subsection{Analysis of Laboratory}

\section{a. Chemical Soil Analysis}

Soil analysis was conducted in Laboratory of the Faculty of Agriculture, Lambung Mangkurat University. Soil chemical parameters consisted of N-total, C-org, $\mathrm{K}_{2} \mathrm{O}$, Fe-soluble, pyrite, $\mathrm{pH}$ and CEC.

\section{b. Phytochemical Analysis}

The test for powders of various parts of Gemor whose active chemical components included alkaloids, flavonoids, steroids, triterpenoids, and phenolics is done by using a suitable reagent one time repetition. The test for active compounds was conducted at the Laboratory of Biochemistry Faculty of Medicine, Lambung Mangkurat University in Banjarbaru with using method of Harborne (1987) [12].

\subsection{Analysis of Data}

The depiction of the active chemical compound of forest plants whose bark is used as an anti-mosquito, then the test result and data content of the active chemical compound was diagramed by scoring technique $(+/-)$. For the results active chemical compounds observed yes then was marked with $(+)$ and if the active chemical compounds observed no then was marked with (-). According to the standard laboratory test of biochemistry, Faculty of Medicine, Lambung Mangkurat University for determining the level, positive on the active compound of secondary metabolites can be looked at the color density from color test results. Determination of the sign by the Biochemistry Laboratory, Faculty of Medicine ULM (Table 1), and based Cahyana and Rachmadi (2011) [9] can be seen in Table 2 .

Table 1. Positive Rate Determination

\begin{tabular}{|l|c|l|}
\hline \multicolumn{1}{|c|}{ Color } & Signs & \multicolumn{1}{c|}{ Information } \\
\hline Color less concentrated & + & Weak positive \\
\hline Slid color & ++ & Medium positive \\
\hline Very dark color & +++ & Strong positive \\
\hline
\end{tabular}

Source: Laboratory of Biochemistry (2014)

Table 2. Positive and Negative Level

\begin{tabular}{|c|c|}
\hline Kind of Signs & Information \\
\hline- & Negative \\
\hline+ & Weak positive \\
\hline++ & Positive \\
\hline+++ & Strong positive \\
\hline++++ & Very strong positive \\
\hline
\end{tabular}

Source: Cahyana \& Rachmadi (2011)

\section{Results and Discussion}

\subsection{The Topography and Microclimate}

Gemor is very common to the flat topography and sometimes inundated with water. It also grows side by side with other plants, so that the intensity of light required only $3-5 \%$. It grows on peat swamp forest ecosystem, that is overgrown by plants and form the structure of the old secondary forest, then it classified plants in association with other plants. Gemor habitat described above is classified as plants that live in old secondary forest. Humidity and temperature are required to grow $88-99 \%$ and $21-32^{\circ} \mathrm{C}$, respectively.

\subsection{Soil}

Gemor plants can be grown only on peat swamp forest community types that are sometimes flooded. The results of chemical analysis of soil where grow gemor are presented in Table 3.

The content of $\mathrm{N}$ (nitrogen) in the soil is included high compared to the value of $\mathrm{N}$ standard soil chemical analysis results according to the Soil Research Institute in Bogor (1980). Some factors can increase the availability of nitrogen in the soil which is comming from stems, twigs, and leaves the dead and unite the shattered lands $[11,24]$.

Value acidity $\left(\mathrm{pH} \mathrm{H}_{2} \mathrm{O}\right)$ in the study area ranged between 3.52 and 3.58, including the highly acidity than standard according to the Soil Research Institute (1980), for standard fertility with $\mathrm{pH}$ values between of 5.5-7.5. This ground also contains pyrite between 0.17 and $0.31 \%$.

C-organic soil atthe observations plots included moderate to high, which is $3.78-9.29 \%$ compared with the standard of the Soil Research Institute (1980), which is 2.01-3.00\%. Some factors may lead to increased soil organic $\mathrm{C}$ from the twigs, branches and leaves which die and then disintegrate united with the ground [11].

The content of CEC (cation exchange capacity) at the observation plots is categorized as very high 41.02 to 50.52 me / 100gr, compared to the standard soil fertility of the Soil Research Institute (1980), which is 17-24 me /100gr. Some factors contained in the content of the CEC are the availability of $\mathrm{K}, \mathrm{Mg}, \mathrm{Ca}, \mathrm{Na}, \mathrm{H}^{+}, \mathrm{Al}^{+++}$and soil organic matter [21].

Table 3. Results of chemical analysis of soil

\begin{tabular}{|c|c|c|c|c|c|c|c|c|c|}
\hline No. & Sample & $\begin{array}{c}\text { N-tot } \\
(\%)\end{array}$ & $\begin{array}{c}\mathrm{C}-\text {-org } \\
(\%)\end{array}$ & $\begin{array}{c}\mathrm{P}_{2} \mathrm{O}_{5} \\
\mathrm{mg} / 100 \mathrm{~g}\end{array}$ & $\begin{array}{c}\mathrm{K}_{2} \mathrm{O} \\
\mathrm{mg} / 100 \mathrm{~g}\end{array}$ & $\begin{array}{c}\text { Fe-soluble } \\
(\mathrm{ppm})\end{array}$ & Pyrite $(\%)$ & $\mathrm{pH}\left(\mathrm{H}_{2} \mathrm{O}\right)$ & $\begin{array}{c}\mathrm{CEC} \\
\mathrm{Me} / 100 \mathrm{~g}\end{array}$ \\
\hline 1. & Plot 1 & 1,43 & 5,88 & 9,10 & 23,45 & 7,04 & 0,24 & 3,52 & 41,02 \\
\hline 2. & Plot 2 & 1,21 & 9,29 & 3,62 & 46,99 & 11,35 & 0,31 & 3,58 & 42,14 \\
\hline 3. & Plot 3 & 1,04 & 3,78 & 9,00 & 25,63 & 4,62 & 0,17 & 3,58 & 50,54 \\
\hline
\end{tabular}


Table 4. Species of gemor and it's characteristic

\begin{tabular}{|c|l|l|ll|l|}
\hline No. & \multicolumn{1}{|c|}{ Kind of species } & \multicolumn{1}{|c|}{ Location found } & \multicolumn{1}{c|}{ Visual observations } & \multicolumn{1}{c|}{ Smelling } \\
\hline 1. & $\begin{array}{l}\text { Gemor Merah (Nothaphoebe } \\
\text { coriacea Kosterm) }\end{array}$ & $\begin{array}{l}\text { KDHTK Tumbang Nusa } \\
-\end{array}$ & $\begin{array}{l}\text { National Park of } \\
\text { Sebangau }\end{array}$ & $\begin{array}{l}\text { Twigs reddish } \\
\text { Bark reddish }\end{array}$ & $\begin{array}{l}\text { The leaves smell sharper (fragrant) } \\
\text { than other parts }\end{array}$ \\
\hline 2. & $\begin{array}{l}\text { Gemor Putih (Nothaphoebe cf } \\
\text { umbelliflora) }\end{array}$ & $\begin{array}{l}\text { National park of } \\
\text { Sebangau }\end{array}$ & $\begin{array}{l}\bullet \\
-\end{array}$ & $\begin{array}{l}\text { Stem yellowish white } \\
\text { Bark yellowish white (pale } \\
\text { white) }\end{array}$ & $\begin{array}{l}\text { Bark and twigs are sharper scent than } \\
\text { the leaves }\end{array}$ \\
\hline
\end{tabular}

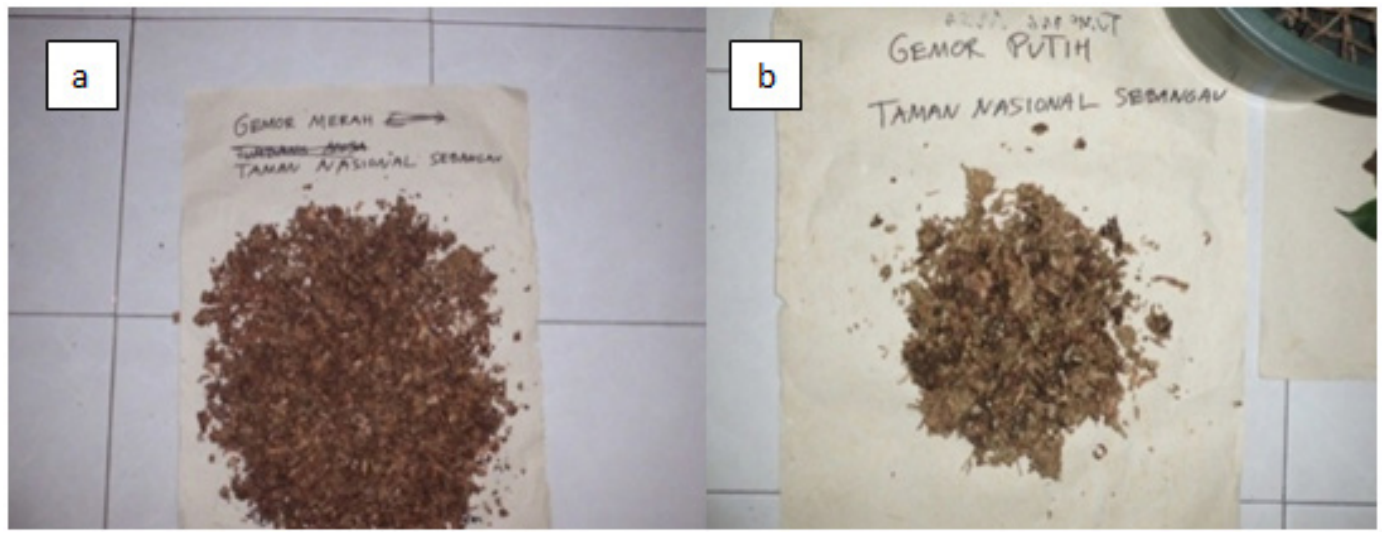

Figure 2. Bark of red and white Gemor

Table 5. Results of phytochemical screening of the various parts of Gemor

\begin{tabular}{|c|c|c|c|c|c|c|c|}
\hline \multirow{2}{*}{ No } & \multirow{2}{*}{ Section } & \multirow{2}{*}{ Species of Gemor } & \multicolumn{5}{|c|}{ Active Compound } \\
\cline { 3 - 8 } & & Alkaloids & Steroids & Flavonoids & Triterpenoid & Phenolic \\
\hline \multirow{2}{*}{1} & \multirow{2}{*}{ bark } & red & + & + & ++ & + & + \\
\hline \multirow{2}{*}{2} & \multirow{2}{*}{ leaves } & white & ++ & + & + & + & + \\
\cline { 3 - 8 } & \multirow{2}{*}{3.} & red & ++ & + & +++ & + & ++ \\
\hline \multirow{2}{*}{ twig } & white & red & + & + & + & + & + \\
\cline { 3 - 8 } & & white & ++ & + & + & + & + \\
\hline
\end{tabular}

\subsection{Species of Gemor}

Gemor can be found in the region of Central Kalimantan, there are two species, namely; red and white Gemor. Red Gemor was found in both locations of research areas, namely: KDHTK Tumbang Nusa and Sebangau National Park. White Gemor otherwise was found only in Sebangau National Park. Results of visual identification of both species can be seen in Table 4.

Table 4 shows that the spread of red Gemor was wider, because it was found in two different locations, and white Gemor only at one location. According to information of bark gatherers of Gemor mostly traded bark of red Gemor, this is due to the difficulty of white Gemor found. They marked the Gemor both chategories of bark and twigs. Bark and twigs of red Gemor looked reddish, while white Gemor tend pale white. This is in line with the result of research [3], which says that the red Gemor is more easily found than white Gemor. The difference can be seen from the color of the bark after the peel that is yellowish white or red. According to community of Gemor with bark color in yellow-white after the peel is a species of red Gemor (Nothaphoebe coriacea Kosterm). Red Gemor was taken from most people because the bark is thicker. White Gemor (Nothaphoebe cf. Umbelliflora) otherwise red color when peeled [16]. However after a day of felling, the color change would occur otherwise, red Gemor looks much red on the twigs, while white Gemor is white-yellow (pale). Likewise on the bark after stripping process more rosy red and bark white Gemor looks white yellowish or whitish (pale), as shown in Figure 2.

Another difference of both species is aroma. Part of bark and branches of white Gemor have a sharper smell than red Gemor, but on the contrary leaves, red Gemor is sharper (fragrant) than white Gemor.

\subsection{Phytochemicals Test}

Results of phytochemical screening of bark, leaves and twigs of red and white Gemor can be seen in Table 5.

Based on test results of bark, leaves and twigs of red and white Gemor (see Table 5), it appears that almost all the 
active compound (alkaloid, steroid, flavonoid, triterpenoid, and phenolic) contained in the various sections ofthe bark, leaves and twigs. It is noticeable that none of the parts were negative (-). The research result is slightly different compared to what had been done by Adi Nugroho (1987) [3], the result of his research said that only in bark of Gemor contained secondary metabolites (steroid, flavonoid, alkaloid, saponin and phenolic), while on the other parts (leaves and twigs) are not all the main content of secondary metabolites. The results of the color test (-) instead of the absolute content of secondary metabolites are not present on the sample, but it can also be caused, it implies that a bit so not detected [3]. This is because the color test is not the concentrated in extract or concentrate, so that detected only the main content. The difference of the results of this study may also be due to differences onsite grew from the tree used as a sample [3]. Hissamples were taken from the territory of East Kalimantan and Kapuas Central Kalimantan, whereas in this study samples were taken from the area Tumbang Nusa and Sebangau Central Kalimantan.

Compared with the results of phytochemical test made by [9] as shown in Table 2, the results indicate that the bark of species Alseodaphne sp. showed positive results (one positive -three positives) except saponins and steroids which were negative (-), then the results of this study only on the content of different steroids. While the content of alkaloid, phenolic and flavonoid showed almost the same results, especially with bark of red Gemor.

\section{Discussion}

Result of phytochemical test of red and white Gemor conducted on the bark, leaves and twigs show that the difference between the two species lies in the dominant the content of alkaloid, flavonoid and phenolic, while the content of steroid and triterpenoid are relative similar. It can be seen from Table 5, where the results showed that the content of steroids and triterpenoids in various anatomical plants (bark, leaves and twigs), both red and white Gemor show sign of positive one $(+)$, which means the positive weak, while the content of alkaloid, flavonoid and phenolicis different (ranging from one positive $(+)$, two positive $(++)$, up to three positive $(+++)$ which means a strong positive, depending on species and anatomical plant (bark, leaves and twigs).

The analysis of active compounds in the bark indicates that the bark of red Gemor compound flavonoid and phenolic are more dominant than the white Gemor (flavonoid and phenolic) content of bark for red Gemor (positive two: ++ ), white Gemor (positive one: + ) the results of this shows why red Gemor is selected to be used as anti-mosquito, because it turns out the two compounds (flavonoid and phenolic) [9]. Both compoundsare toxic harmful to insects. Flavonoid included grade phenolic and flavonoid group is natural insecticide. Gemor potent enough to be used as raw material for mosquito coils [9]. Flavonoids are phenolics compounds as anti-microbial, anti-virus, anti-fungi and insects as well [14]. Red Gemor has higher phenolic and flavonoid compared to white Gemor, wherein the compound is toxic and as natural insecticide, that's why red Gemor is more exploited for purposes of insect repellent, as well as due to the red Gemor bark thicker than white Gemor. Compared with other plants with the active compound, content is the same as according to [1], leaves Jeringau components containing secondary metabolite, such as: alkaloid, flavonoid, saponin, steroid, and Triterpenoid which serves as a repellent mosquitoes or kill mosquito. It shows that any other plants have secondary metabolites, which have the same functions as a natural insecticide.

The results of the analysis of active compounds in the leaves, show that the leaves of red Gemor have an advantage over white Gemor leaves, not only because the content of flavonoids and phenolic have more dominant than leaves of white Gemor, but also compound of alkaloids. Alkaloids in bark of red Gemor was lower than white Gemor, otherwisealkaloids inleaves of red Gemor were more dominant than white Gemor. These results indicate that, other parts of Gemor, especially red Gemor, during which only a waste of harvesting and not utilized, actually also has a great potential to be used. Leaves have actually the content of alkaloid, flavonoid and phenolic more dominant than in the bark.

The high content of flavonoid and phenolic in red Gemor (both in the bark and leaves) can be used as anti-mosquito, and also has the potential to be used as a medicine and materials for antioxidants. Phenolics compounds as antioxidant can stabilize the radical free to complete the lack of electron free radicals and inhibit the chain reaction of free radical formation [15]. A phenolic compound has the ability to change or reduce free radicals and also as a free radical. Flavonoids are a class of organic pigments that do not contain molecular nitrogen [8]. The combination of various kinds of pigments forms the pigmentation of the leaves, flowers, fruits and seeds of plants. These pigments are attractant for insects and are agents of pollination. Pigments are also useful for humans and one of the important benefits as an antioxidant. Sirait (2007) [23] states that for humans, flavonoids in small doses work as a stimulant on the heart and blood vessel capillaries, as a diuretic and antioxidant in fats. The flavonoids in the human body to function as an antioxidant are very good for cancer prevention [2]. The benefits of flavonoids among others, is to protect the cell structure, improve the effectiveness of vitamin $\mathrm{C}$, anti-inflammatory, preventing bone loss, and as antibiotics.

The high content of alkaloid found in the leaves of red Gemor, and also present in the bark of white Gemor could also be a compound that has potential as an insecticide. As expressed by [9], which states the alkaloid has properties metabolites on one or more amino acids. Other toxic effects can be more complex and dangerous to insects, which interfere with the activity of tyrosine which is an enzyme 
essential for skin hardening of insects. It shows that the bark of white Gemor and red leaves (which have a high alkaloid content) also have potential as anti-mosquito (insects) .In habitat, Gemor most common and most widely used is red Gemor. Result of this research, the multiplication of white Gemor should be considered, given the content of its alkaloids high enough (especially in the bark), so that the possibility can be used as raw material for medicine, and toxic to insects. As stated by [12], which states that the alkaloids are class of secondary plant the largest and often toxic, so often used widely in the medical field. Alkaloids are the most organic compounds found in nature, the leaves have a bitter taste [13]. Functions for the plant alkaloid is as toxins against insects or plant eating animals and as a factor of influence grows. Alkaloids have properties against one or some acid metabolites amino [9]. Effect of regular toxoids is more complex and dangerous to insects, which disrupts the activities of an enzyme essential tyrosine and causes the hardening of the skin to insects. The alkaloid content in the extract of larvacides can stimulate the endocrine glands to produce hormones edicson [5]. Increasing this hormone will cause the failure of metamorphosis in larvae of Aedes aegypti, so pupa will not happen. Metabolites of alkaloids commonly found in plants that can fend off insects. These metabolites are found, among others, in tobacco plants. In tobacco, nicotine is found that can help ward off an insect attack. These secondary metabolites can be extracted from plants and used as a natural insecticide. Alkaloids compound in other plants such as tobacco has the same function, namely as a natural insecticide.

The twig shows that red Gemor has very dominant with flavonoids, while twig white Gemor is dominant with alkaloid and phenolics. These results indicate that the twigs, as part of the leaf, (both branches and twigs red and white Gemor) which is a waste of harvesting has potential to be used as a mosquito, antioxidants and other drugs.

If we connect the phytochemical screening test results on various anatomical Gemor with the smell acuity test results, the outline indicates that the pungent odor probably derived from a compound belonging to the class of alkaloid. It can be seen that the leaves of red Gemor which physically leaves more fragrant than the leaves white Gemor, alkaloid content of the leaves red Gemor is more dominant than the leaves white Gemor, as well as bark and twigs of Gemor white indicates the level of fragrance is even worse than the bark and twigs of red Gemor. Result of phytochemical test shows that the white bark and twigs Gemor, alkaloid content is also higher than the alkaloid in the barks and twigs of red Gemor.

Depth study of the qualitative test to various parts of the Gemor followed by a quantitative test in order to know its contents is more clearly. It is more important to know pyret in compounds from various parts of plants such as Gemor, so that we can determine the species Gemor and various anatomical plants has the potential great used as anti-mosquito. Depth study of the content of other compounds, and its potential as an antioxidant, anti-cancer also need to be deepened, as well as other drug is needed because in many parts of the plant such as Gemor there are various compounds (especially alkaloid, flavonoid and phenolic).That is the big question mark why the importer would only import bark intact. This raises a big question mark, and needs to be done more in-depth research the utilizations are more potent than bark, not only as a mosquito repellent but for other uses.

\section{Conclusions}

1 Gemor lives on land that is relatively flat and stagnant water. Gemor associated with other plants and requires only $3-5 \%$ of light intensity, humidity $88-99 \%$, temperature $21-32^{\circ} \mathrm{C}$. Soil type of gemor's habitat found in the observation plots was peat with a $\mathrm{pH}$ from 3.52 to 3.58 , N1.04-1.43\%, C3.78- 9.29\%, CEC 41.02 to $50,52 \mathrm{me} / 100 \mathrm{gr}$.

2 Gemor species found in Tumbang Nusa Regions and Sebangau National Park (Central Kalimantan) there are two species, namely: red Gemor (Nothaphoebe coriacea (Kosterm.) and white Gemor (Nothaphoebe cf. Umbelliflora). The difference can be seen from the color of bark and sharpness of the smell of leaves. The smell of red Gemor leaves and bark and twigs of white Gemor, probably derived from a compound belonging alkaloid. High of alkaloid content in that part section indicates potentially as a repellent.

3 Part of Gemor is exploited, especially from the bark of the red Gemor due to high economic value. Bark of red gemor is thicker than white Gemor. The bark has compound high content of flavonoid and phenolic substances which are toxic and to be going to serve as a natural insecticide.

4 Leavesof red Gemor is potential to be developed as anti-mosquito, antioxidants and others, because it has alkaloid, flavonoid and phenolic even more dominant than from the bark

5 White Gemor, especially the bark and twigs also have the potential to be developed as a source of anti-insect, because its alkaloid is higher than the bark of red Gemor.

\section{REFERENCES}

[1] Abdullah, Susanti., Bialangi, Nurhayati., and Duengo, Suleman. 2013. Uji Aktivitas Repellent Nyamuk Dari Ekstrak Daun Jeringau (A. Calamus L.) (Mosquito Repellent Activity Test of Leaf Extract Jeringau (A. Calamus L) Jurusan Pendidikan Kimia Fakultas Matematika dan Ilmu Pengetahuan Alam Universitas Negeri Gorontalo. Gorontalo.

[2] Achmad, S.A, 1986.Kimia organik bahan alam (Chemical organic of Natural Ingredients). Buku Materi Pokok, modul 4 -6 , Universitas Terbuka. Jakarta. 
[3] Adinugroho, Wahyu C. 2009. Karakteristik Habitat Dan Ekologi Pohon Penghasil Kulit Kayu Gemor (Characteristics of Habitat and Ecological Producers of Gemor).Forest Researcher (Forda-Indonesia). Bogor

[4] Adinugroho, Wahyu C., Mukhlisi \& Sidiyasa, K. 2010. Mengenal Gemor (Introduction of Gemor). Forest Researcher (Forda-Indonesia). Bogor.

[5] Adam. 2005. Uji Toksisitas Ekstrak Biji Srikaya (Annona squamosa Linn) Terhadap Larva Aedes aegypti.[Thesis].Ilmu Kesehatan Kerja. Universitas Gadjah Mada. Yogyakarta.

[6] Anonimous.1985. Cara Pembuatan Simplisia (Crude Production Method). Departemen Kesehatan Republik Indonesia. Jakarta.131 hal.

[7] Andriyani, Susy. 2010. Konservasi Gemor (Nothaphoebe coriacea (Korstern) Di Kalimantan (Conservation of Gemor (Nothaphoebe coriacea (Korstern) in Kalimantan). Balai Penelitian Kehutanan Banjarbaru. Banjarbaru, Kalimantan Selatan.

[8] Bhat, Sujata V., Nagasampagi, B A., and Meenakshi, S. 2009 Natural Products: Chemistry and Application. Narosa Publishing House, New Delhi. India.

[9] Cahyana, Budi T., dan Rachmadi, Andri T, 2011. Pemanfaatan kulit kayu gemor (AlseodaphneP.) dan Cangkang Kemiri (Ateurites Molucca) Untuk Obat Nyamuk alami (The Use of Bark of Gemor for Repellent). Peneliti Baristand lndustri. Banjarbaru

[10] Djauhari, Mohammad. 2009. "Gemor Potensi Hasil Hutan Bukan Kayu". 09 Mei 2014. http://kpshk.org/reportasekomunitas/read/2009/07/13/60/gem or-potensi-hasil-hutan bukan-kayu.kpshk

[11] Dwidjoseputro, D., 1983. Pengantar Fisiologi Tumbuhan (Introduction of Plant Physiology). PT. Gramedia. Jakarta. 225 hal.

[12] Harborne, Jeffrey B. 1987. Metode Fitokimia (Phytochemical Method). Penuntun Cara Modern Menganalisa Tumbuhan. Terbitan ke-2. Penerbit ITB. Bandung.

[13] Kusuma, Ratna. 2011. Identifikasi Senyawa Bioaktif Pada Tumbuhan Meranti Merah (Shorea Smithiana Symington). Biologi FMIPA Universitas Mulawarman. Samarinda.

[14] Nopianti, Surya.,Astuti, Dwi., dan Darnoto,Sri. 2008. Efektivitas Buah Belimbing Wuluh (averrhoabilimbi l.) Untuk Membunuh Larva Nyamuk Anopheles aconitus InstarIII. Jurnal Kesehatan. Vol. I No. 2 Desember 2008, Hal 103-114.
Kesehatan Masyarakat Fakultas Ilmu Kesehatan Universitas Muhammadiyah Surakarta. Surakarta.

[15] Poedjiadi, Annadan Supriyanti, F.M.T. 2009. Dasar-dasar BIOKIMIA.UI-Press. Jakarta

[16] Panjaitan, Sudin.dan Susanti, Pratnasari D. 2010. Prospek Dan Teknik Pengembangan Gemor (Nathaphoebe Coriaceae Kosterm) Di Kalimantan. Balai Penelitian dan Pengembangan Industri Banjarbaru. Banjarbaru, Kalimantan Selatan.

[17] Pusat Penelitian Tanah. 1983. Klasifikasi Kesesuaian Lahan. Proyek Penelitian Pertanian Menunjang Transmigrasi. No.29b/1983, Bogor

[18] Santosa, Purwanto B. 2011. Teknik Budidaya Gemor. Laporan Hasil Penelitian. BPK Banjarbaru. Banjarbaru, Kalimantan Selatan.

[19] Santosa, Purwanto B., Panjaitan, Sudin.,dan Eryanto, Leo. J. 2013. Gemor (Nothaphoebecoriacea Kosterm) :HHBK di Hutan Rawa Gambut, Potensi dan Tantangannya.Prosiding Seminar Nasional Peranan Hasil Litbang Hasil Hutan Bukan Kayu Dalam Mendukung Pembangunan Kehutanan.Pusat Penelitian dan Pengembangan Peningkatan Produktivitas Hutan, Badan Penelitian dan Pengembangan Kehutanan BPK Banjarbaru. Banjarbaru, Kalimantan Selatan.

[20] Santosa, Purwanto B., dan Panjaitan, Sudin. 2013. Gemor (Notaphoebe Coriacea) Hasil Hutan Bukan Kayu (HHBK) potensial di Hutan Rawa Gambut. Kementrian Kehutanan, Badan Penelitian dan Pengembangan Kehutanan, Balai Penelitian Kehutanan Banjarbaru 2013. Banjarbaru, Kalimantan Selatan.

[21] Sembiring, S., 2008. Sifat Kimia dan Fisik Tanah Pada Areal Bekas Tambang Bauksit di Pulau Bintan, Riau (Chemical Properties and Soil Physical Logged- In Bauxite Mine in Bintan Island, Riau) Info Hutan Vol. V No.2 : 123-134.

[22] Setiawan, Nugraha. 2005. Teknik Sampling (Sampling Method). Department Pendidikan Nasional Inspektorat Jenderal Diklat Metodologi Penelitian Sosial Parung Bogor, 25 - 28 Mei 2005.Universitas Padjadjaran. Jatinangor, Jawa Barat.

[23] Sirait, M. 2007. Penuntun Fitokimia dalam Farmas (Phytochemicals guiding Pharmacy) Institut Teknologi Bandung, Bandung.

[24] Sutedjo M.M., Kartasapoetra A.G., 1991. Pengantar Ilnu Tanah Terbentuknya tanah dan Tanah Pertanian (Introduction of Establishment of Soil Science and Land Agricultural land) Penerbit Rineka Cipta, Jakarta 